Tropical Journal of Pharmaceutical Research August 2015; 14 (8): 1371-1381

ISSN: $1596-5996$ (print); 1596-9827 (electronic)

(C) Pharmacotherapy Group, Faculty of Pharmacy, University of Benin, Benin City, 300001 Nigeria.

All rights reserved.

Available online at http://www.tjpr.org

Original Research Article

http://dx.doi.org/10.4314/tjpr.v14i8.8

\title{
Zingiber officinale Roscoe Aqueous Extract Modulates Matrixmetalloproteinases and Tissue Inhibitors of Metalloproteinases Expressions in Dengue Virus-infected Cells: Implications for Prevention of Vascular Permeability
}

\author{
Binita Koirala Sharma ${ }^{1,2 *}$, David Charles Klinzing ${ }^{3,4}$ and John Donnie Ramos ${ }^{1,5}$ \\ ${ }^{1}$ The Graduate School, University of Santo Tomas, España, Manila, Philippines, ${ }^{2}$ Department of Microbiology, Manipal College \\ of Medical Sciences, Pokhara, Nepal, ${ }^{3}$ St Luke's Medical Center, Research and Biotechnology Division, Quezon City, ${ }^{4}$ AlT \\ Biotech Pte Ltd, Singapore, ${ }^{5}$ Research Center for the Natural and Applied Sciences, and College of Science, University of \\ Santo Tomas, España, Manila, Philippines
}

*For correspondence: Email: binita_keshab@yahoo.com; Tel: +977 9856036122

\begin{abstract}
Purpose: To investigate the effect of the aqueous extract of Zingiber officinale Roscoe. (ZOA) rhizome on the activity and expression of matrix metalloproteinase (MMP)-2, MMP-9, tissue inhibitor of metalloproteinase (TIMP)-1 and TIMP-2 using an in vitro model of Dengue virus (DV) infection.

Methods: Z. officinale rhizomes were extracted with water by continuous shaking for 5 days. The total phenolic content in extract was measured by Folin-Ciocalteu method. High performance liquid chromatography (HPLC) was employed to define qualitative and quantitative content of [6]-gingerol in ZOA. The median inhibitory concentration (IC50) value of ZOA for Vero cells was determined by 3-(4,5 dimethylthiazol-2- yl)-2,5-diphenyltetrazolium bromide (MTT) assay. To induce MMPs production, Vero cells were infected with DV3. The modulatory effect of ZOA on the activity and expression of MMP-2, MMP-9, TIMP-1 and TIMP-2 were assessed using gelatin zymography and quantitative Real-time polymerase chain reaction (RTPCR), respectively.

Results: The yield of the ZOA was $7.98 \%$. Total phenolics in ZOA was $68.17 \pm 0.28 \mathrm{mg} \mathrm{GAE} / \mathrm{g}$ of extract and it contained $29.32 \pm 1.97 \mathrm{mg}$ 6-gingerol/g of extract.The half-maximal inhibition concentration $\left(I C_{50}\right)$ of ZOA was $348.8 \mu \mathrm{g} / \mathrm{mL}$ for Vero cells. DV infection of Vero cells significantly elevated the production of soluble gelatinolytic MMP-2 and to a lesser extent, MMP-9, and their activities were significantly inhibited by ZOA in a dose-dependent manner. A significant down-regulation of MMP-2, MMP-9 mRNA expression and up-regulation of TIMP-1, TIMP-2 mRNA expression were observed in DV-infected Vero cells following treatment with ZOA, and it occurred in a dose-dependent manner.

Conclusion: The findings of this study suggest that ZOA may ameliorate plasma leakage in dengue virus infection and decrease the chances of severe dengue complications, dengue haemorrhagic fever (DHF) and dengue shock syndrome (DSS) by inhibiting the activities and expression of MMP-2 and MMP-9 while upregulating the expression of TIMP-1 and TIMP-2.
\end{abstract}

Keywords: Zingiber officinale, Dengue virus, Matrix metalloproteinases, Tissue inhibitor, Vascular leakage, 6-Gingerol

Tropical Journal of Pharmaceutical Research is indexed by Science Citation Index (SciSearch), Scopus, International Pharmaceutical Abstract, Chemical Abstracts, Embase, Index Copernicus, EBSCO, African Index Medicus, JournalSeek, Journal Citation Reports/Science Edition, Directory of Open Access Journals (DOAJ), African Journal Online, Bioline International, Open-J-Gate and Pharmacy Abstracts 
the Americas [1]. Infection by any of the four serotypes of dengue viruses (DV-1, $-2,-3$ and -4 ) may result in either a relatively benign fever, called dengue fever (DF), a fatal disease, such as dengue haemorrhagic fever (DHF) or dengue shock syndrome (DSS) [2]. DV infection causes an estimated 100 million new cases of DF, 500 000 cases of DHF and 25000 deaths annually [3].

Disease severities following DV infection are caused by increased vascular permeability leading to hypovolemic shock. Matrix metalloproteinases (MMPs) are believed to play a key role in promoting such severities. MMPs are zinc-dependent endopeptidases and comprise a large family of enzymes with different abilities to degrade specific extracellular matrix (ECM) components $[4,5]$. The role of MMP-2 and MMP-9 produced by DV-infected cells in inducing in vitro endothelial cell monolayer permeability and vascular leakage in mice has been established [6,7]. Moreover, significant elevation of circulating MMP-9 and MMP-2 in dengue patients and their association with disease severity and plasma leakage compared to healthy controls is well established $[8,9]$. The tissue inhibitor of metalloproteinases (TIMP) family, including TIMP-1, TIMP-2, TIMP-3 and TIMP-4, regulates the multifunctional metalloproteinase activities. TIMPs inhibit MMP activities and modulate critical signaling pathways independent of metalloproteinase inhibition [10]. DV infection enhanced the production of TIMP-1 and TIMP-2 but do not restore the physiological balance between the MMP and TIMP leading to vascular permeability $[4,5,11]$.

In Asian countries, ginger (Zingiber officinale Roscoe) has been used as a herbal medicine to treat a wide range of disorders such as inflammation, dyspepsia, nausea, vomiting, pain, the common cold and diarrhoea [12]. Phenylpropanoid-derived compounds including 6-gingerol and shogaols are biologically active components present in ginger. They are reported to be effective against in vitro model of various disease conditions by modulating the secretion, activity and expression of MMP-2 and MMP-9 [13-17]. However, the efficacy of ginger extracts in modulating MMP and TIMP cellular response in DHF/DSS has not been explored. Currently, there is neither an approved vaccine nor any anti-viral drug available for prevention and treatment of dengue and patients are treated only symptomatically $[18,19]$. In this study we evaluated the modulatory effect of $Z$. officinale rhizome aqueous extract on activity and expression of MMP-2, MMP-9, TIMP-1 and TIMP-2. The findings of this study may indicate the potential of ginger extract for clinical use in DV infection, which may perhaps decrease the chance of severe dengue complications, DHF and DSS.

\section{EXPERIMENTAL}

\section{Collection and preparation of aqueous extract}

$Z$. officinale rhizomes used in this study were collected from the local supplier of Klondykes Tuba, Benguet, Philippines and were authenticated at National Museum, Manila, Philippines. Voucher specimens were processed at the laboratory of Research and Biotechnology Division of St. Luke's Medical Center, Quezon City, Philippines. The rhizomes were then cleaned, peeled and cut into sections of $2 \pm 1$ $\mathrm{mm}$ thickness followed by drying at $60{ }^{\circ} \mathrm{C}$ and grinding in a blender until a fine powder was produced. The powder obtained was packed in polyethylene bags and stored in a refrigerator at $4{ }^{\circ} \mathrm{C}$ for further uses. The extraction protocol used was adopted from optimized procedures of the antiviral study group of Research and Biotechnology Division, St. Lukes Medical Center. Thirty grams of powdered rhizome was kept in the flask filled with $350 \mathrm{~mL}$ of water and was subjected for continuous shaking for five days. The plant-water suspension was centrifuged at $15000 \mathrm{rpm}$ for $20 \mathrm{~min}$ at $4{ }^{\circ} \mathrm{C}$. Supernatant was filtered. The filtrate was then collected and evaporated to near dryness using a rotary evaporator (Heidolph WB 2000) at 300 $\mathrm{mmHg}$ at $70{ }^{\circ} \mathrm{C}$ and lyophilized to obtain $Z$. officinale rhizomes aqueous extract (ZOA). Two batches of $30 \mathrm{~g}$ powdered samples were extracted and extracts from two batches were pooled together to avoid batch-to-batch variations.

\section{Determination of total phenolic contents and [6]-gingerol content in ZOA}

Weighed amount of lyophilised ZOA was dissolved in water to a concentration of $3 \mathrm{mg} / \mathrm{mL}$. Total phenolic constituents of ZOA were determined by utilizing the Folin-Ciocalteu reagent, in accordance to a method of Loh et al with gallic acid as standard [20]. The total phenolic content was determined from a gallic acid calibration curve and expressed as $\mathrm{mg}$ of gallic acid equivalent (GAE) per gram of extract. All measurements were performed at least in triplicate, and presented as mean \pm SD . 
The standards and samples were filtered through a $0.22 \mu \mathrm{m}$ syringe filter before injecting onto high performance liquid chromatography (HPLC) system, adopted from Loh et al [20]. The contents of 6-gingerol in the extracts was analyzed by HPLC using Spectra HPLC system (TSP, USA) equipped with P2000 binary pump, AS1000 autosampler, UV2000 UV detector and SW4000 system controller. ZOA $(20 \mu \mathrm{L})$ was subjected to HPLC for the 6-gingerol analysis. Separation was performed on a Lichrospher R18 (250 mm x $4.6 \mathrm{~mm}, 5$ micron 100A Luna 5u R18 column) from Phenomenex USA by maintaining the isocratic binary flow rate $(1 \mathrm{ml} / \mathrm{min})$ using a mixture of HPLC grade acetonitrile and water $(55: 45 \mathrm{v} / \mathrm{v})$. The compounds were identified and quantified based on retention times using 6gingerol as HPLC external standard which was purchased from Sigma-Aldrich (USA) (Cat. No. 29150-4) [21]. A standard curve of the different concentrations of 6-gingerol at 25,50,100, 200, 400 and $800 \mu \mathrm{g} / \mathrm{mL}$ was prepared. The concentration of 6 -gingerol in the ZOA was determined by linear regression.

\section{Cell culture and dengue virus propagation}

C6/36 cells, BHK-21 and Vero cells were obtained from the Research and Biotechnology Division (RBD), St. Lukes Medical Center, Philippines. Vero cells were grown and maintained in minimum essential medium (MEM) containing $10 \%$ fetal bovine serum (FBS) in a 5 $\% \mathrm{CO}_{2}$ incubator at $37{ }^{\circ} \mathrm{C}$. C6/36 cells were grown and maintained in MEM containing $10 \%$ FBS at $28{ }^{\circ} \mathrm{C}$ in the absence of $\mathrm{CO}_{2}$. The clinical isolate of DV3 (strain SLMC-50) was obtained from RBD and was propagated in $\mathrm{C} 6 / 36$ cells, as previously described with slight modification [22].

DV3 was titrated by foci forming assay as described previously by Zandi with slight modification [23]. Briefly, a BHK-21 [C-13] cell monolayer was prepared in 96 wells cell culture microplate. After attaining $\sim 80 \%$ confluency, growth medium was removed and the cells were infected by DV-3 $(100 \mu \mathrm{L}$ of serially diluted infected culture fluid) for $2 \mathrm{~h}$ to allow virus attachment and penetration into the host cell. Thereafter, the wells were overlaid with $2 \%$ carboxymethylcellulose in Eagle's Minimum Essential Medium (2 \% CMC-EMEM) and incubated for $48 \mathrm{~h}$ at $37{ }^{\circ} \mathrm{C}$ and $5 \% \mathrm{CO}_{2}$.

Following incubation, wells were washed carefully with $1 \mathrm{x}$ phosphate buffered saline until residual CMC-EMEM was completely removed. Thereafter, $5 \%$ formaldehyde (JK Baker, USA) was added to fix the cells for $2 \mathrm{~h}$ at room temperature (RT) followed by washing (three times) with PBS. Fixed cells were permeabilized using $50 \mu \mathrm{L}$ of $1 \%$ Nonidet P-40 (Sigma-Aldrich, Singapore) for $1 \mathrm{~h}$. The cells were washed three times with PBS and blocked using $50 \mu \mathrm{L}$ of BlockAceTM (Wako, Japan) for $1 \mathrm{~h}$. Following blocking of nonspecific sites and another three washing with PBS, $50 \mu \mathrm{L}$ of 1:10 dilution of dengue virus-specific monoclonal antibody, clone 6B9, (Dengue Research Group, RBD-SLMC) was used to detect the presence of viral antigens. The reaction was allowed to take place for $1 \mathrm{~h}$ at RT.

The cells were then washed three times with PBS and incubated with goat anti-rabbit IgG conjugated with horse-radish peroxidase (HRP) at final concentration of 1:100 (Calbiochem, USA) as a secondary antibody for $1 \mathrm{~h}$ at RT. Finally, $50 \mu \mathrm{L}$ of $3,3^{\prime}$-diaminobenzidine (DAB) peroxidase substrate (Biorad, USA) was added to each well to stain the virus foci. Immunostaining of infected cells was monitored for 5 to $10 \mathrm{~min}$. When color development was observed, the reaction was stopped by filling wells with $200 \mu \mathrm{L}$ of distilled water. Viral foci were viewed, counted and photographed using Olympus CKX41 inverted microscope equipped with DP21 camera and expressed as FociForming-Unit (FFU).

\section{MTT cytotoxicity assay}

Cytotoxicity of the ZOA was determined using MTT assay as previously described with slight modifications [24]. Briefly, monolayers of Vero cells were seeded in 96-well microplates and treated with different concentrations of ZOA in triplicates. Cells were treated for three days at 37 ${ }^{\circ} \mathrm{C}$. At the end of the incubation period, $100 \mu \mathrm{L}$ of MTT (Sigma-Aldrich, Singapore) in MEM (0.5 $\mathrm{mg} / \mathrm{mL}$ ) solution was added to each well. The microplate was kept at $37^{\circ} \mathrm{C}$ for $4 \mathrm{~h}$ followed by adding solubilization solution/stop mix to each well. The optical density of the wells was measured at $570 \mathrm{~nm}$ using 96-well plate reader (Dynex Technologies Microplate Reader, USA). Median Inhibitory Concentration $\left(\mathrm{IC}_{50}\right)$ values were generated from the dose-response curve using Graphpad Prism 6. All final concentrations of ZOA for treatment were adjusted based on the $\mathrm{IC}_{50}$. Bleomycin Sulfate was used as positive control. Negative control was treated with media alone (without any inhibitors).

\section{Infection of Vero cells with DV3 and collection of conditioned media (CM)}

Infection of cells with DV3 and collection of CM was performed according to a method described previously by Luplertlop and Misse with slight 
modifications [7]. Monolayer of $2.5 \times 10^{5} \mathrm{cells} / \mathrm{mL}$ was exposed to DV3 at multiplicity of infection (MOI) of $1 \mathrm{ffu} / \mathrm{cell}$ for $4 \mathrm{~h}$ to allow the virus to adsorp with gently shaking of flasks every 30 min, washed twice to remove excess virus, and further cultured at $37^{\circ} \mathrm{C}$ with $5 \% \mathrm{CO}_{2}$ for $24 \mathrm{~h}$ in MEM, without FBS. The conditioned cell culture media from DV-infected Vero cells were collected in sterile $15-\mathrm{mL}$ conical tubes and was concentrated by size exclusion ultrafiltration using AmiconTM-4 Centrifugal Filter Units (Millipore). Thus obtained conditioned media were aliquoted in $1.5 \mathrm{~mL}$ micro-centrifuge tubes and were stored at $-20{ }^{\circ} \mathrm{C}$ until use. All experiments were performed using virus-free (negative reverse transcription-PCR concentrated $\mathrm{CM}$.

\section{Determination of MMP activity by gelatin zymography}

Substrate gel zymography of the activity of MMP2 and MMP-9 was performed with a Mini-Protein II apparatus (Bio-Rad), according to a method described previously $[26,27]$.

The concentrated $\mathrm{CM}$ was re-suspended in $5 \mathrm{X}$ sample buffer; $3.72 \mathrm{~mL} 1 \mathrm{M}$ Tris-HCl pH 6.8, 0.6 $\mathrm{mL} 1 \%$ bromophenol blue (Sigma-Aldrich, Singapore) in distilled water, $1.68 \mathrm{~mL}$ distilled water, $6 \mathrm{~mL}$ glycerol (Invitrogen, USA)]. Sample in buffer $15 \mu \mathrm{L}$ was loaded in alternating well. Four $\mu \mathrm{L}$ of BenchMarkTM Protein Ladder (Invitrogen, USA) was used as a molecular weight marker. Running conditions were as follows: $70 \mathrm{~V}$ for the first $30 \mathrm{~min}$ and increased to $100 \mathrm{~V}$ until the loaded samples were run at least $3 / 4$ of the gel. After electrophoresis, the gels were soaked in $2.5 \%$ Triton X-100 ( $3 \times 20 \mathrm{~min})$ in a plastic container at room temperature and placed in a mechanical rotator for gentle agitation followed by rinsing in distilled water. For gelatinase inhibition assays, ZOA and Epigallocatechin-3-gallate (EGCG) were freshly solubilized in the incubation buffer used for developing the zymogram; the gel slab was cut into slices corresponding to the lanes which were put in different tanks and incubated at $37^{\circ} \mathrm{C}$ for $20 \mathrm{~h}$ in the $10 \mathrm{~mL}$ of incubation buffer, containing $6.67 \mathrm{~mL}$ of $1.5 \mathrm{M}$ Tris- $\mathrm{HCl}$ buffer $(\mathrm{pH} 8.8)$, and $0.4 \mathrm{~g} \mathrm{CaCl}_{2} \cdot 2 \mathrm{H}_{2} \mathrm{O}$ and $0.02 \%$ Brij-58 filled to $100 \mathrm{~mL}$ with distilled $\mathrm{H}_{2} \mathrm{O}$ without $\mathrm{ZOA}$ (control without inhibitor) or with ZOA $(6.25,12.5,25$ and $50 \mu \mathrm{g} / \mathrm{mL}$ ) and $100 \mu \mathrm{M}$ of EGCG. After incubation, the developing buffer was decanted and the slabs were stained for $15-30 \mathrm{~min}$ in 0.1 $\%(\mathrm{w} / \mathrm{v})$ Coomassie blue R-250 in $30 \%$ methanol and $10 \%$ acetic acid, and de-stained in the same solution without the Coomassie blue dye for 1030 min. After de-staining, a light translucent band over a blue background was detected for gelatinase activity. Gel band images were captured by a digital camera and were analyzed for optical density through the Image Lab (Biorad). Gelatinase proteins that pass across the gel matrix digest the gelatin substrate incorporated in the gel such that MMP-2 and MMP-9 can be detected at $67 \mathrm{kDa}$ and $92 \mathrm{kDa}$ as clear zones against the dark background $[28,29]$. EGCG was tested for MMPs inhibitory activity as a control since green tea polyphenols caused a strong inhibition of the gelatinolytic activities of MMP-2 and MMP-9, and of the elastinolytic activity of MMP-12 through the compound EGCG [30]. In order to determine the type of gelatinase observed on the zymograms, $10 \mathrm{mM}$ ethylenediaminetetraacetic acid (EDTA) was added to the buffer during the incubation period. All procedures were performed as they were for gels without EDTA in the incubation buffer.

\section{Real-time RT-PCR for MMP-2, MMP-9, TIMP-1 and TIMP-2 mRNA}

The levels of MMP-2, MMP -9, TIMP-1 and TIMP-2 gene expression were analyzed with real time RT-PCR as described previously with slight modifications [31]. RNA was extracted from Vero cells which were seeded at a density of $5 \times 10^{4}$ cells $/ \mathrm{mL}$ and infected with DV3 (MOI of $1 \mathrm{ffu} /$ cell) for $48 \mathrm{~h}$ at $37^{\circ} \mathrm{C}$ in presence and absence of various concentrations of ZOA and $100 \mu \mathrm{M}$ EGCG. After $48 \mathrm{~h}$, the cells were collected by centrifugation (1500 rpm, $5 \mathrm{~min}, 4^{\circ} \mathrm{C}$ ) and total RNA was extracted using RNeasyTM mini kit (Qiagen, Germany) according to the manufacturer's protocol. cDNA was prepared from $1 \mu \mathrm{g}$ of the total RNA using iScriptTM Reverse Transcription Supermix for RT-qPCR (Bio-Rad Laboratories Inc., Hercules, CA, USA) according to the manufacturer's protocol. Subsequent Real-timePCR amplification was perfomed using SsoFastTM EvaGreen ${ }^{\circledR}$ Supermix (Bio-Rad Laboratories Inc., Hercules, CA, USA) according to the manufacturer's instruction. The PCR was run for denaturation at $94{ }^{\circ} \mathrm{C}$ for 3 min followed by 45 cycles, consisted of denaturing at $94{ }^{\circ} \mathrm{C}$ for $30 \mathrm{~S}$, annealing step for $45 \mathrm{~S}$ (at $56{ }^{\circ} \mathrm{C}$ for MMP-2 and GAPDH, $59{ }^{\circ} \mathrm{C}$ for MMP-9, $60^{\circ} \mathrm{C}$ for TIMP-1 and TIMP-2) and extension step (at $72{ }^{\circ} \mathrm{C}$ for $30 \mathrm{~S}$ ), followed by a final elongation step (at $72{ }^{\circ} \mathrm{C}$ for $1 \mathrm{~min}$ ) [6,32]. The PCR primers were used for amplifying MMPs and TIMPs are shown in Table 1.

\section{Statistical analysis}

Statistical analysis was carried out using GraphPad Prism 6 software. All the results were 
expressed as Mean \pm Standard Deviation (SD). The statistics were performed by comparing results from treated DV infected cells with untreated DV infected cells control using Analysis of Variance (ANOVA) followed by Dunnett's Multiple Comparison Test for significant differences. $P<0.05$ was considered statistically significant.

\section{RESULTS}

Total phenolic and 6-gingerol contents of ZOA

Table 1: Primers used for amplifying MMPs and TIMPs
The dry extract weight of ZOA was $4.790 \mathrm{~g}$, giving a yield of $7.98 \%$. As assessed by the Folin-Ciocalteu's method, the total phenolic content of the extract was presented as GAE with reference to the gallic acid standard curve (y $\left.=0.0012 x+0.0126, R^{2}=0.9992\right)$ plotted using the average absorbance values of triplicate sets of data against concentrations of gallic acid in $\mathrm{mg} / \mathrm{mL}$. ZOA contained total phenolics of $68.07 \pm$ $0.16 \mathrm{mg} \mathrm{GAE} / \mathrm{g}$ of the extract.

HPLC chromatogram of ZOA is shown in Figure 1. $B$ and ZOA contained $29.04 \pm 2.63 \mathrm{mg}$ 6gingerol/g extract.

\begin{tabular}{llll}
\hline Gene & Forward primer (5'-3) & Reverse primer (5'-3) & Reference \\
\hline MMP-2 & AGGATCATTGGCTACACACC & AGCTGTCATAGGATGTGCCC & {$[6]$} \\
MMP-9 & CGCAGACATCGTCATCCAGT & GGATTGGCCTTGGAAGATGA & {$[6]$} \\
TIMP-1 & GCAACTCCGGACCTTGTCATC & AGCGTAGGTCTTGGTGAAGC & {$[32]$} \\
TIMP-2 & GTAGTGATCAGGGCCAAAG & TTCTCTGTGACCCAGTCCAT & {$[32]$} \\
GAPDH & CCACCCATGGCAAATTCCATGGCA & TCTAGACGGCAGGTCAGGTCCACC & {$[6]$} \\
\hline
\end{tabular}

A.
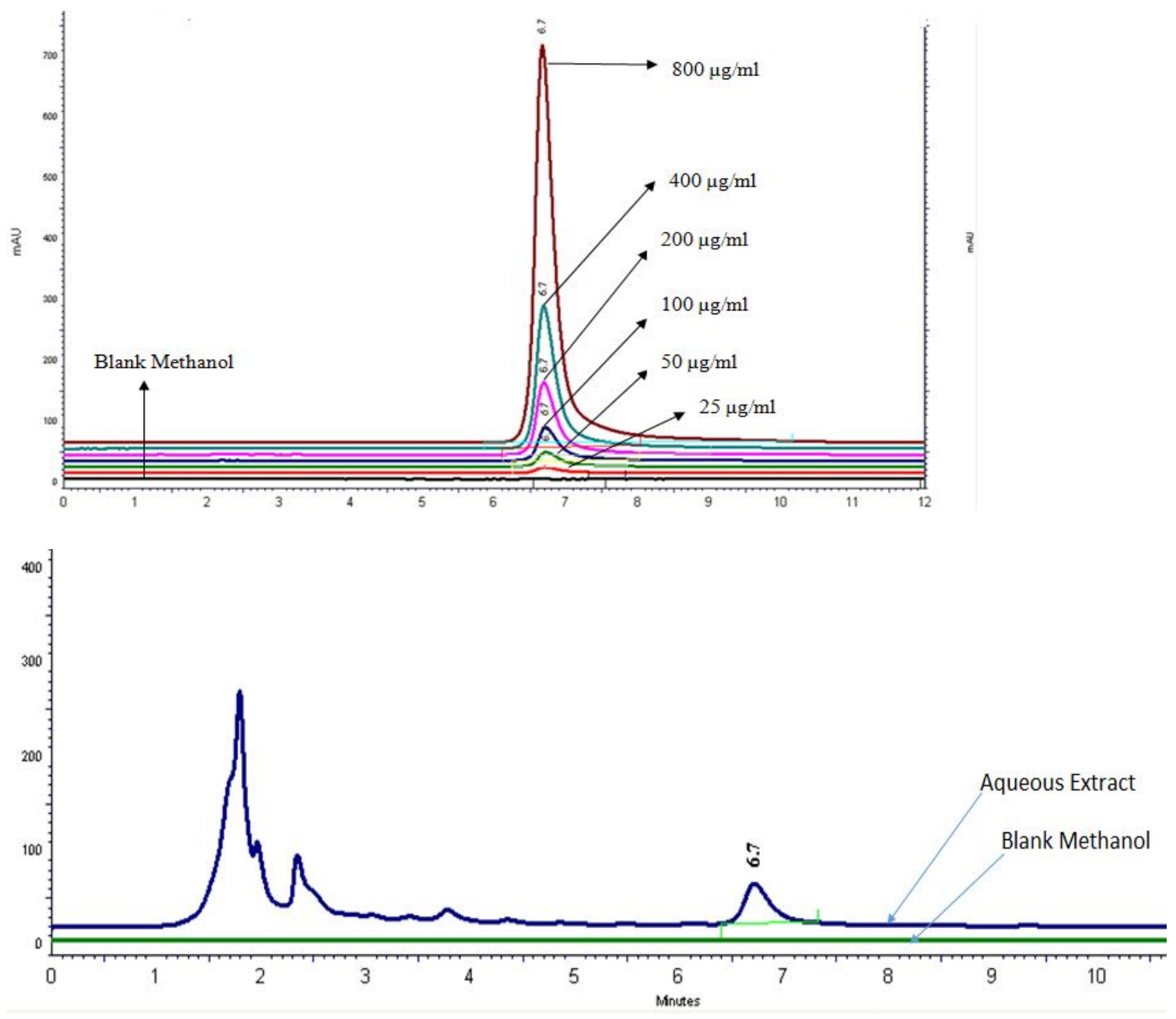

Figure 1: 6-Gingerol content of ZOA. A) Typical HPLC chromatogram of A) Overlay of 6-gingerol standards (25, $50,100,200,400$ and $800 \mu \mathrm{g} / \mathrm{mL})$; B) ZOA (3 mg/mL) in 55:45(v/v) acetonitrile-water mobile phase 


\section{Cytotoxicity of ZOA against Vero cells}

The $\mathrm{IC}_{50}$ of ZOA was $348.8 \mu \mathrm{g} / \mathrm{mL}$ for Vero cells when added directly to the cells (Figure 2). The assay demonstrated that $50 \mu \mathrm{g} / \mathrm{mL}$ ZOA exerted no significant effects on cell viability and this concentration was used as maximum for all the subsequent studies.

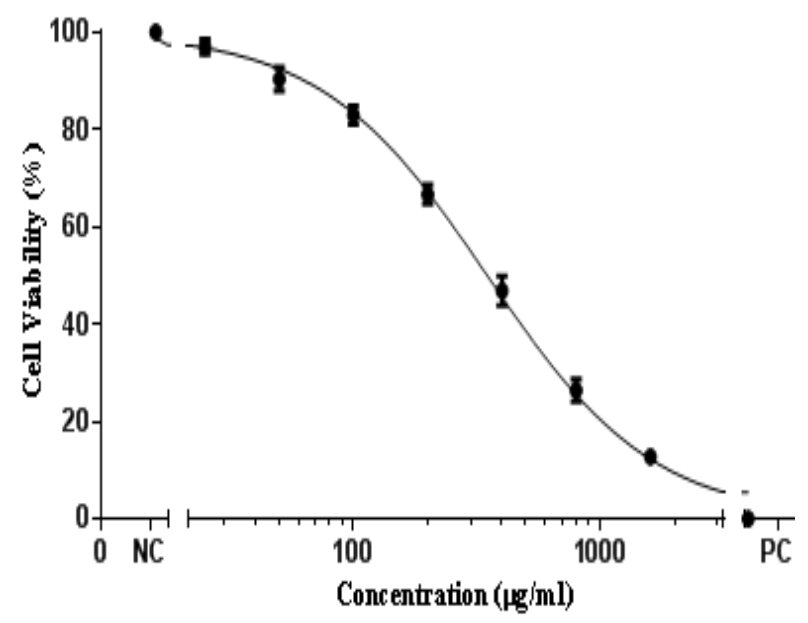

Figure 2: Cytotoxicity of ZOA on Vero cells. MTT assay was used to evaluate the cytotoxicity of the ZOA. All experiments were conducted in triplicates

\section{DV infection of Vero cells triggers overproduction of MMP-2 and MMP-9}

DV infection significantly enhanced MMP-2 proteolytic activity at $67 \mathrm{kDa}$ (band corresponded to the molecular weight of MMP-2) and MMP-9 at $92 \mathrm{kDa}$ (band corresponded to the molecular weight of pro-MMP-9) to a lesser extent with $p<$ 0.0001 compared to non-infected cells. This enhancement was reduced after treatment with EDTA (metalloproteinase inhibitor, Figure 3).

\section{Inhibitory effect of ZOA on DV-induced MMP- 2 and MMP-9 activities}

The activities of MMP-2 and MMP-9 in CM collected from DV-infected Vero cells were decreased by ZOA treatment in dose-dependent manner (Figure 4). $100 \mu \mathrm{M}$ EGCG significantly reduced the DV-induced MMP-2 and MMP-9 activities. At the ZOA concentration of 6.25 $\mu \mathrm{g} / \mathrm{mL}$ treatment, no difference observed in the MMP-2 activity compared to the untreated CM. MMP-2 activity was reduced significantly to 88.7 $(p=0.0243), 38.3$ and $16.3 \%(p<0.0001)$ in response to ZOA-treatment with concentrations of $12.5,25$ and $50 \mu \mathrm{g} / \mathrm{mL}$ respectively. Similarly, there was no difference observed in MMP-9 activity at CM treated with 6.25 and $12.5 \mu \mathrm{g} / \mathrm{mL}$ of ZOA while the activity of MMP-9 was significantly reduced to $58.3 \%$ and $34.0 \%(p<$ 0.0001 ) in response to ZOA-treatment with 25 and $50 \mu \mathrm{g} / \mathrm{mL}$ respectively. MMP-2 and MMP-9 activities were reduced to 34.3 and $28.5 \%(p<$ 0.0001) respectively with $100 \mu \mathrm{M}$ EGCG treatment.

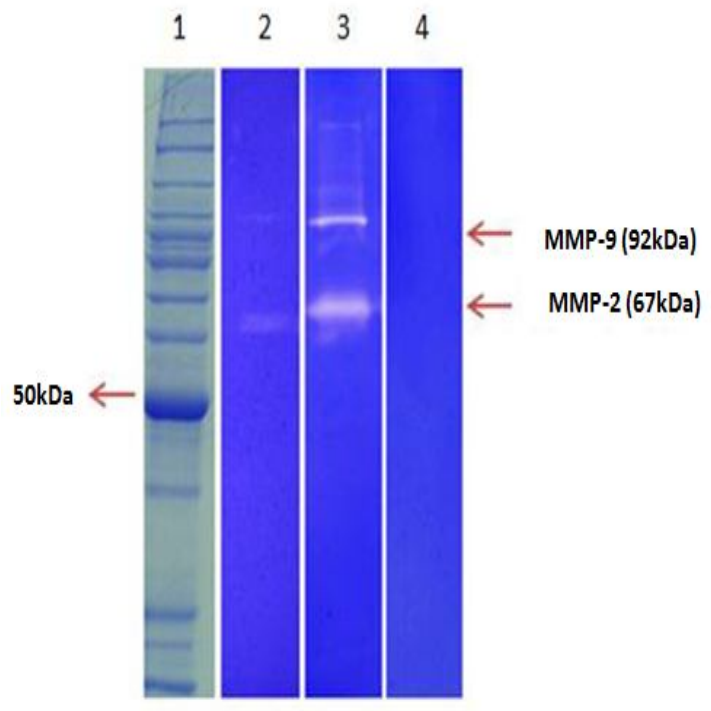

A.

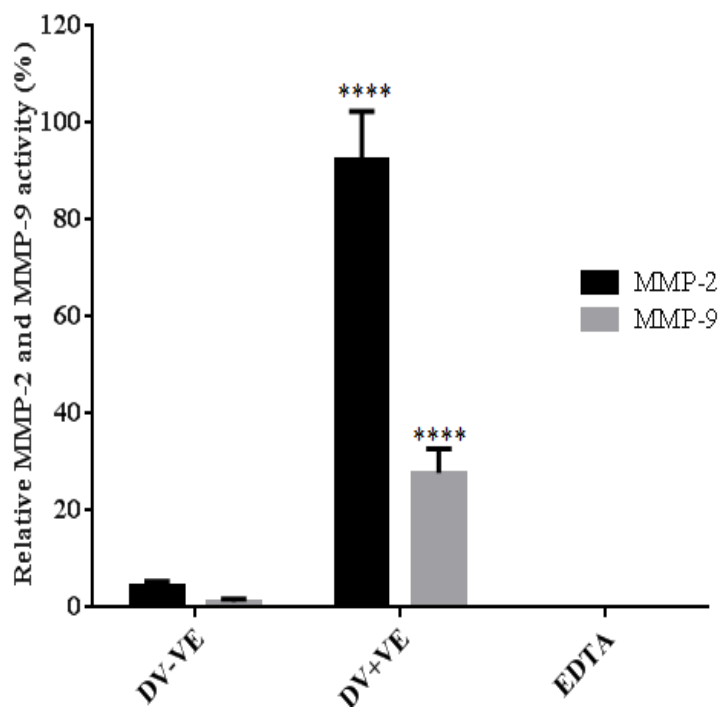

Figure 3: Detection of proteolytic activity of MMP-2 and MMP-9 in CM collected from DV infected Vero cells. (A) Using $8 \%$ gelatin-zymography (1-4), showing the ladder (BenchMarkTM, Invitrogen) (1), Concentrated CM from non-infected cells (2), concentrated CM from DV infected cells (3). Concentrated CM from DV infected cells treated with $10 \mathrm{mmol} / \mathrm{I}$ EDTA (4). (B) Quantitative analysis of the bands. Each bar represents the mean \pm S.D. calculated from three independent experiments; ${ }^{* * * *}$ above bar indicates $p<0.0001$ relative to non-infected cells

Trop J Pharm Res, August 2015; 14(8): 1376 


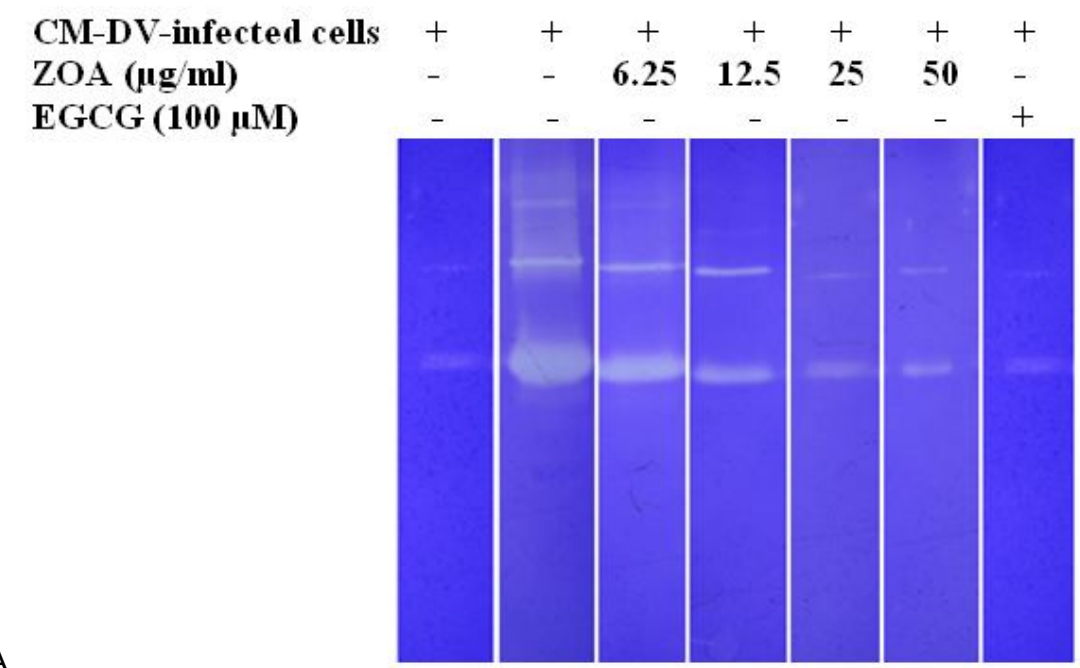

A.

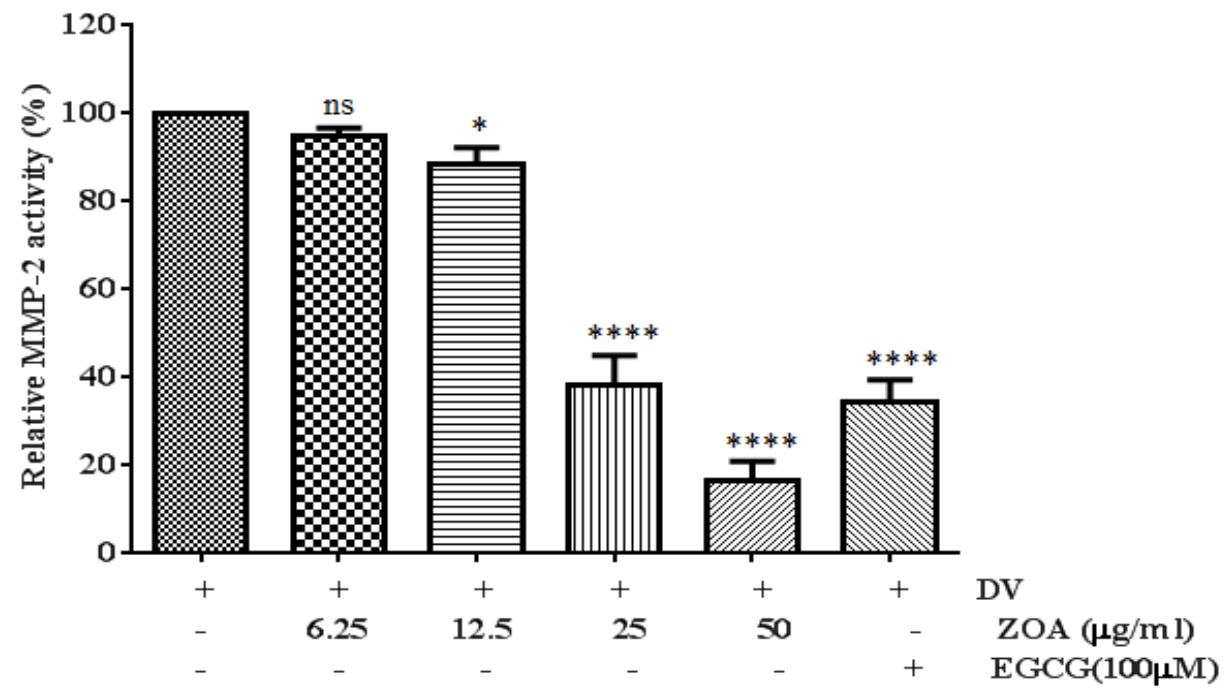

B.

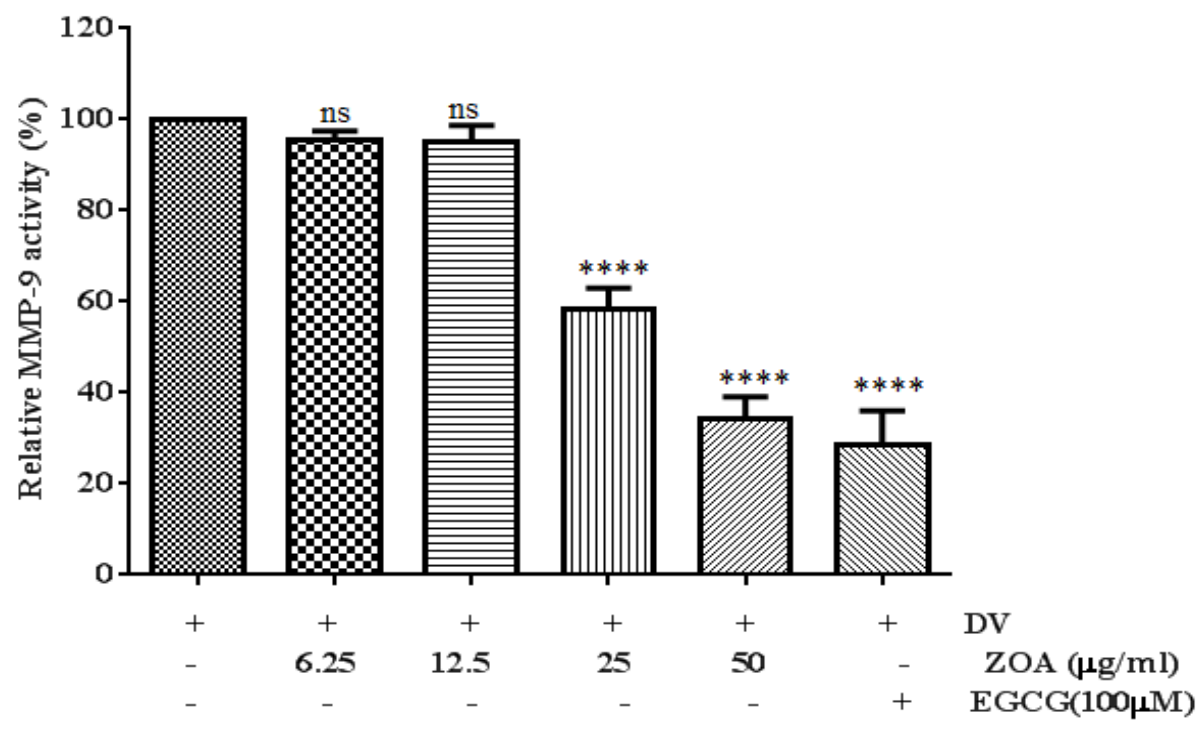

Figure 4: Dose dependent inhibition of MMP-2 and MMP-9 activity after treatment with ZOA. (A) Photograph of the MMP bands, which are representative of three independent experiments $(A)$. Quantitative analysis of the bands for MMP-2 and MMP-9 respectively (B and C). Each bar represents the mean \pm S.D. calculated from three independent experiments are indicated by not significant (ns), $p<0.05\left(^{*}\right)$ and $p<0.0001\left(^{* * *}\right)$ 
ZOA transcriptionally regulates MMP-2, MMP9, TIMP-1 and TIMP-2

The expression of MMP-2, MMP-9 was decreased while the expression of TIMP-2 and TIMP-1 were increased with an increased concentration of ZOA, whereas that of the internal control (GAPDH) remained unchanged (Figure 5). At the ZOA concentration of 6.25 $\mu \mathrm{g} / \mathrm{mL}$ no difference observed in the MMP-2 gene expression levels. MMP-2 was reduced to $0.87(p=0.0036), 0.56$, and 0.19 folds $(p<$ 0.0001 ) in response to ZOA treatment at concentrations of $12.5 \mu \mathrm{g} / \mathrm{mL} 25 \mu \mathrm{g} / \mathrm{mL}$ and 50 $\mu \mathrm{g} / \mathrm{mL}$ respectively while $100 \mu \mathrm{M}$ of EGCG (Control) significantly reduced the expression of MMP-2 to 0.82 folds $(p=0.0002)$ (Figure 5. A). At 6.25 and $12.5 \mu \mathrm{g} / \mathrm{mL}$ no difference observed in the MMP-9 expression levels. The expression of MMP-9 was significantly down-regulated to $0.82(p=0.0001)$ and $0.76(p<0.0001)$ in response to ZOA treatment of 25 and $50 \mu \mathrm{g} / \mathrm{ml}$ respectively. $100 \mu \mathrm{M}$ EGCG significantly downregulated the expression of MMP-9 to 0.78 folds $(p<0.0001)$ (Figure 5B).

There was significant increase in the expression level of the TIMP-1 gene in the ZOA treated DV infected cells with $12.5,25$ and $50 \mu \mathrm{g} / \mathrm{mL}$ to 1.93 , 2.66- and 3.07-fold ( $p<0.0001)$ respectively (Figure 5C). Similarly expression of TIMP-2 gene was increased to $1.92,3.86$ and 4.78 folds in ZOA-treated cells with $12.5,25$ and $50 \mu \mathrm{g} / \mathrm{ml}$ respectively. No difference was observed at 6.25 $\mu \mathrm{g} / \mathrm{mL}$ of ZOA treatment. EGCG significantly upregulated the expression of TIMP-1 to 1.34 fold and TIMP-2 to 2.13 folds in comparison to DV infected cells (Figure 5D).

\section{DISCUSSION}

Despite tremendous research efforts for its control and treatment, there is neither vaccine nor specific treatment available for dengue fever, and patients are currently treated only symptomatically. The main strategy for combating dengue infection is through control of the mosquito vector population. On the other hand, vaccine development has been hampered by the complexities of the pathogen itself, the four antigenically distinct serotypes, and the likelihood that immune enhancement is playing a role in disease pathogenesis. Therefore studies of novel therapeutic strategies are needed to improve the clinical outcome of DV infection. The role of MMP-2 and MMP-9 in vascular leakage associated with DHF and MMP regulation by TIMPs has been established [6-9]. Control of
MMPs and TIMPs activity is of great significance in preventing vascular leakage caused by dengue virus (DV) infection. Ginger (Z. officinale rhizome) is one of the most frequently and heavily consumed dietary condiments throughout the world [33]. Biologically active compounds of ginger, including 6-gingerol and shogaols were reported to be effective against in vitro model of various disease conditions by modulating the MMP-2 and MMP-9 gene activity, protein expression and secretion [14-17]. However, the efficacy of $Z$. officinale rhizome extracts in modulating MMPs and TIMPs cellular response in DHF/DSS has not been hitherto explored.

In this study, it has been demonstrated that DV infection significantly enhanced MMP-2 proteolytic activity and MMP-9 to a lesser extent. This enhancement was reduced after treatment with EDTA (metalloproteinase inhibitor). These data confirmed that these enzymes are metalloproteinases as these proteinases are dependent upon calcium for their optimal activity, and hydrolyse gelatin.

We investigated the inhibitory effects on the gelatinolytic activity of MMP-2 and MMP-9 by aqueous extract from rhizomes of $Z$. officinale, and by known MMPs inhibitor, such as EGCG. Proteolytic activity was indicated by the presence of clear bands on a dark background and the intensity of the band was shown to be proportional to activity of MMP-2 and MMP-9. Results from this study demonstrate dosedependent inhibition of MMP-2 and MMP-9 activities by ZOA in conditioned media collected from DV-infected Vero cells as demonstrated by gelatin zymography. Likewise, results presented here confirmed that $Z$. officinale rhizome aqueous extract has strong concentrationdependent modulatory activity on mRNA expression of MMP-2, MMP-9, TIMP-1 and TIMP-2. Indeed ZOA significantly downregulated the mRNA expression of MMP-2 and MMP-9, whereas it up regulated the expression of TIMP-1 and TIMP-2 in DV infected cells in dosedependent manner as demonstrated by real time RT-PCR.

The anti-MMPs activity of $Z$. officinale rhizome extract has been attributed to its naturally occurring compounds such as gingerols and shoagols. In this study, the amount of total phenolics in ZOA was $68.07 \pm 0.16 \mathrm{mg} \mathrm{GAE} / \mathrm{g}$ of extract and it contained $29.04 \pm 2.63 \mathrm{mg} \mathrm{6}$ gingerol/g of extract. The increase in the total phenolics content and 6-gingerol with increase in concentration of the extract may account for the concentration-dependent modulatory activities of 


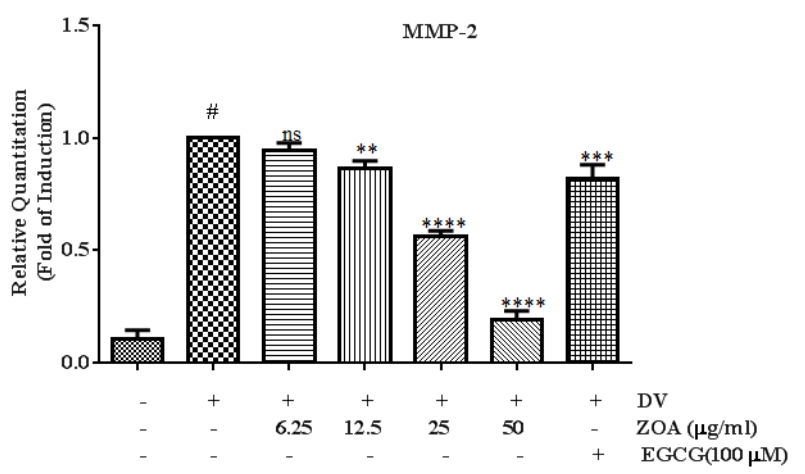

A.

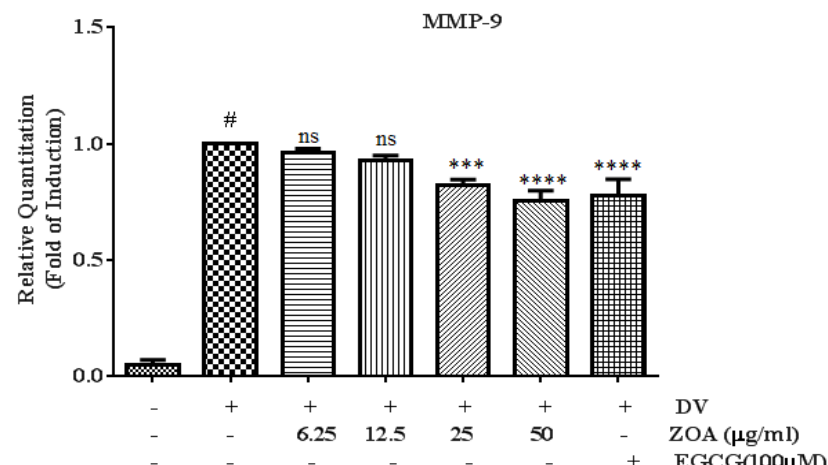

B.

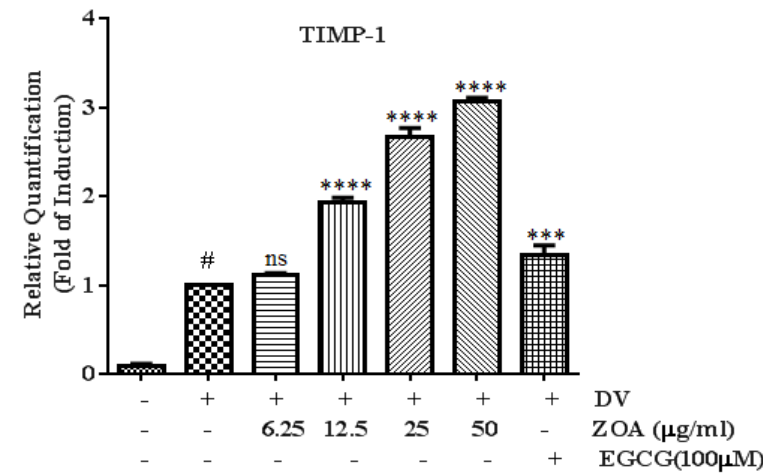

C.

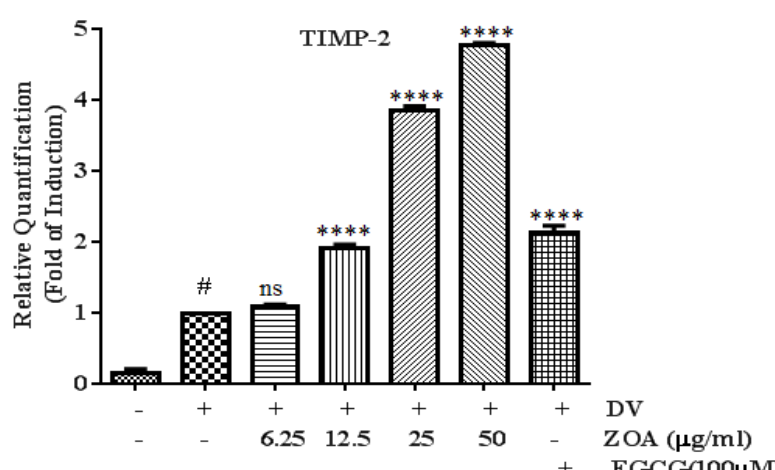

D.

Figure 5: Concentration-dependent modulatory effects of ZOA on expression of MMPs and TIMPs in DV infected Vero cells. (A) MMP-2, (B) MMP-9, (C) TIMP-1, (D) TIMP-2. Vero cells were plated at a density of $5 \times 10^{4}$ cells $/ \mathrm{mL}$ with MEM supplemented with $2 \%$ FBS and infected with DV3 for $48 \mathrm{~h}$ at $37^{\circ} \mathrm{C}$ in presence and absence of

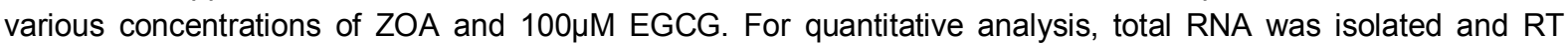
followed by real time PCR was performed to investigate the gene expression level. Each bar represents the mean \pm S.D. calculated from three independent experiments with GAPDH used as the internal control. Columns, mean $\left(\mathrm{n}=3\right.$ ); bars, SD. (\#) $\mathrm{p}<0.05$ versus control (noninfected cells), $p=$ not significant $(\mathrm{ns}), p<0.01\left({ }^{* *}\right), p<$ $0.001\left(^{* * *}\right)$ and $p<0.0001\left(^{* * * *}\right)$, statistically significant compared with DV-infected untreated control 
ZOA on MMPs and TIMPs activities and mRNA expression.

Our observations of modulatory effect of ZOA on MMPs and TIMPs activity and expression are supported by previous findings. Lee et al demonstrated that 6-gingerol inhibited metastasis through dose dependent inhibition of cell adhesion, invasion, motility and activity of MMP-2 and MMP-9 in MDA-MB-231 human breast cancer cells [15]. Similarly, Weng et al showed that 6-shogaol and 6-gingerol exerted antiinvasive activity against hepatoma cells through regulation of MMP-9 and TIMP-1 in a dose dependent manner [17]. Kim and Kim also suggested that 6-gingerol inhibited the invasiveness of pancreatic cancer (PANC-1) cells by decreasing the levels of protease, MMP2 , and MMP-9 [34]. All these reports supported our findings that the natural compounds such as 6 -gingerol, present in Z. officinale rhizomes, play important anti-MMPs role.

\section{CONCLUSION}

The aqueous extract of $Z$. officinale rhizome may play an important role in the regulation of plasma leakage in dengue infection and decrease the chances of severe dengue complications by inhibiting the activity and expression of MMP-2 and MMP-9 while upregulating the expression of TIMP-1 and TIMP-2. Therefore, it can help in the development of new anti-dengue agents.

\section{ACKNOWLEDGEMENT}

This work was supported by Research and Biotechnology Division (RBD), St Luke's Medical Centre of Quezon City, Manila, Philippines through a grant from Philippines Council for Health Research and Development (PCHRD) and Department of Science and Technology (DOST) for antiviral research project. The authors thank $\mathrm{Dr}$ Filipinas Natividad, Vice President, RBD, for kindly providing laboratory facilities as well as cell lines and DV isolates for this study. Thanks also to all dengue research groups of RBD for their kind support.

\section{REFERENCES}

1. McBride WJH, Bielefeldt-Ohmann H. Dengue viral infections; pathogenesis and epidemiology. Microbes Infect 2000; 2:1041-1050.

2. Gubler DJ. Dengue and dengue haemorrhagic fever. Clin Microbiol Rev 1998; 11:480-496.
3. WHO: Dengue and Dengue Haemorrhagic Fever. Geneva: World Health Organisation; 2002. Fact Sheet No. 117.

4. Rodríguez D, Morrison CJ, Overall CM. Matrix metalloproteinases: What do they not do? New substrates and biological roles identified by murine models and proteomics. BBA - Mol Cell Res 2010; 1803: 39-54.

5. Visse R. Matrix Metalloproteinases and Tissue Inhibitors of Metalloproteinases: Structure, Function, and Biochemistry. Circ Res 2003; 92: 827-839.

6. Luplertlop N, Misse D, Bray D, Deleuze V, Gonzalez JP, Leardkamolkarn V, Yssel H, Veas F. Dengue-virusinfected dendritic cells trigger vascular leakage through metalloproteinase overproduction. EMBO Rep 2006; 7:1176-1181.

7. Luplertlop N, Misse D. MMP Cellular responses to dengue virus infection-induced vascular leakage. Japan. J Infect Dis 2008; 61: 298-301.

8. Kubelka CF, Azeredo EL, Gandini M, Oliveira-Pinto LM, Barbosa LS, Damasco PV, Avila CAL, Motta-Castro $A R C$, Cunha RV, Cruz OG. Metalloproteinases are produced during dengue fever and MMP-9 is associated with severity. J inf 2010; 61:501-505.

9. Cornelia AM, van de Weg, Cláudio S. Pannutib, HenkJan van den Ham, Evaldo S.A. de Araújo, Lucy SV Boas, Alvina C. Felix, Karina I. Carvalhod, José E. Levi, Camila M. Romano, Cristiane C. Centrone et al., Serum angiopoietin-2 and soluble VEGF receptor 2 are surrogatemarkers for plasma leakage in patients with acute dengue virus infection. J Clin Virol 2014; 60:328-335.

10. Sun J, Matrix Metalloproteinases and Tissue Inhibitor of Metalloproteinases are essential for the inflammatory response in cancer cells. J Signal Transuct 2010 2010: Article ID 985132, 7 pages.

11. Goldberg GI, Marmer, BL, Grant, GA, Eisen AZ, Wilhelm $S$, He CS. Human 72-kilodalton type IV collagenase forms a complex with a tissue inhibitor of metalloproteases designated TIMP-2. Proc Natl Acad Sci USA 1989; 86: 8207-8211.

12. Ali BH, Blunden G, Tanira MO, Nemmar A. Some phytochemical, pharmacological and toxicological properties of ginger (Zingiber officinale Roscoe): a review of recent research. Food Chem Toxicol 2008; 46: 409-420.

13. Kundu JK, Na HK, Surh YJ. Ginger-derived phenolic substances with cancer preventive and therapeutic potential. Forum Nutr 2009; 61: 182-192.

14. Yanti: Anti-metalloproteinase-9 activities of selected Indonesian Zingiberaceae rhizome extracts in lipopolysaccharide-induced human vascular endothelial cells in vitro. Am J Biochem Biotech 2011; 7: 1-9.

15. Lee HS, Seo EY, Kang NE, Kim WK. [6]-Gingerol inhibits metastasis of MDA-MB-231 human breast cancer cells. J Nutr Biochem 2008; 19:313-319. 
16. Ling H, Yang H, Tan SH, Chui WK, Chew EH. 6-Shogaol, an active constituent of ginger, inhibits breast cancer cell invasion by reducing matrix metalloproteinase- 9 expression via blockade of nuclear factor- $k B$ activation. Br J Pharmacol 2010; 161:1763-1777.

17. Weng CJ, Wu CF, Huang HW, Ho CT, Yen GC. Antiinvasion effects of 6-shogaol and 6-gingerol, two active components in ginger, on human hepatocarcinoma cells. Mol Nutr Food Res 2010; 54:1618-1627.

18. Narvaez F, Gutierrez G, Perez MA, Elizondo D, Nunez A, Balmaseda A, Harris E. Evaluation of the traditional and revised WHO classifications of Dengue disease severity. PLoS Negl Trop Dis 2011; 5: e1397.

19. Murphy BR, Whitehead SS. Immune response to dengue virus and prospects for a vaccine. Annu Rev Immunol 2011; 29: 587-619.

20. Loh DSY, Er HM, Chen YS. Mutagenic and antimutagenic activities of aqueous and methanol extracts of Euphorbia hirta. J Ethnopharmacol 2009; 126: 406-414.

21. Puengphian C, Sirichote A. [6]-gingerol content and bioactive properties of ginger (Zingiber officinale Roscoe) extracts from supercritical CO2 extraction. As J Food Ag-Ind 2008; 1: 29-36.

22. Jain M, Ganju L, Katiyal A, Padwad Y, Mishra, KP, Chanda S, Karan D, Yogendra KMS, Sawhney RC. Effect of Hippophae rhamnoides leaf extract against Dengue virus infection in human blood-derived macrophages. Phytomedicine 2008; 15: 793-799.

23. Zandi K, Teoh BT, Sam SS, Wong PF, Mustafa MR, AbuBakar S. In vitro antiviral activity of fisetin, rutin and naringenin against dengue virus type-2. J Med Plants Res 2011; 5: 5534-5539.

24. Denizot F, Lang R. Rapid colorimetric assay for cell growth and survival. Modifications to the tetrazolium dye procedure giving improved sensitivity and reliability. J Immunol Methods 1986; 89: 271-277.

25. Deubel V, Laille M, Hugnot JP, Chungue E, Guesdon JL, Drouet MT, Bassot S, Chevrier D. Identification of dengue sequences by genomic amplification: rapid diagnosis of dengue virus serotypes in peripheral blood. J Virol Methods 1990; 30: 41-54.

26. Misse D, Esteve PO, Renneboog B, Vidal M, Cerutti M, St Pierre Y, Yssel H, Parmentier M, Veas F. HIV-1 glycoprotein 120 induces the MMP-9 cytopathogenic factor production that is abolished by inhibition of the p38 mitogen-activated protein kinase signaling pathway. Blood 2001; 98: 541-547.

27. Seo UK, Lee YJ, Kim JK, Cha BY, Kim DW, Nam KS, $\mathrm{Kim}, \mathrm{CH}$. Large-scale and effective screening of Korean medicinal plants for inhibitory activity on matrix metalloproteinase-9. J Ethnopharmacol 2005; 97: 101-106.

28. Troeberg L, Nagase H. Zymography of Metalloproteinases. Current Protocols in Protein Science 2004; 33:21.15: 21.15.1-21.15.12.

29. Shimokawa K, Katayama M, Matsuda K, Takahashi H, Hara I, Sato H, Kaneko S. Matrixmetalloproteinase (MMP)-2 and MMP-9 activities in human seminal. Mol Hum Reprod 2002; 8:32-36.

30. Demeule M, Brossard, M, Page M, Gingras D, Beliveau R. Matrix metalloproteinase inhibition by green tea catechions. Bioochimica et Biophysica Acta 2000; 1478: $51-60$

31. Sen T, Moulik S, Dutta A, Choudhury PR, Banerji A, Das $S$, Roy $M$, Chatterjee A. Multifunctional effect of epigallocatechin-3-gallate (EGCG) in downregulation of gelatinase-A (MMP-2) in human breast cancer cell line MCF-7. Life Sci 2009; 84:194-204.

32. Ottino $P$, Taheri $F$, Bazan HE. Platelet-activating factor induces the gene expression of TIMP-1, -2, and PAI1: imbalance between the gene expression of MMP-9 and TIMP-1 and -2. Exp Eye Res 2002, 74: 393-402.

33. Surh YJ. Molecular mechanisms of chemopre $v$ ventive effects of selected dietary and medici-nal phenolic substances. Mutat Res 1999; 428: 305-27.

34. Kim SO, Kim MR. [6]-gingerol prevents disassembly of cell junctions and activities of MMPs in invasive human pancreas cancer cells through ERK/NFkappa B/Snail signal transduction pathway. EvidBased Complement Alternat Med 2013; eCAM 2013:761852. Doi: 10. 1155/2013/761852. 